\title{
The Psycho and the Physical in Psycho-Physical Actioning.
}

How the technique of Psycho-physical Actioning can be used successfully both as a text analysis tool and as an actor training method.

by Nick Moseley, Central School of Speech and Drama, University of London

Much of Stanislavski's work was devoted to the pursuit of a rehearsal technique which allowed the actor both to live truthfully within the given circumstances of a play, and to speak the text of that play as if the words were his own, however many times the play was performed.

Many trainee actors struggle with the notion of 'owning' the text in the fullest sense. This may be because they have learned the words and intonations in a way which is disconnected from their own thoughts and physicality. To put it another way, they may never have really explored, in a precise and systematic way, how each phrase informs a moment of thought and intention, and how those moments combine into a psycho-physical journey whose rhythm is both that of the written text and that of the living actor. For an actor to be truly 'present' in performance there must be a synergy of thought, body and text so that all three move forward together.

In his latter years Stanislavski worked from the notion that there is a reciprocal relationship between mind and body. The body may respond to thought, feeling and intention, but this process can also happen in reverse. A physical action carried out with conviction and context can generate, or at least stimulate, thought, feeling and intention, which the text then makes specific.

The Method of Physical Actions, which became the dominant rehearsal technique of the Moscow Art Theatre in the decades following Stanislavski's death, takes as its starting principle the idea that a physical action which is motivated from the character's objective and carried out truthfully within the world of the play, has a much more stimulating effect on the actor's creative imagination than an intention which exists only in the actor's head. A scene, 
therefore, should be 'mapped' as a series of connected practical or gestural physical actions, which the actor learns alongside the text. The actions themselves are like physicalised 'thoughts', which express in various ways the subtext and character intention, and which can (in theory) be performed over and over again without losing their power to stir the imagination.

'Psycho-physical Actioning' could be described as a refinement of this technique, yet its origins lie not in the Method of Physical Actions, but in the political theatre of 1970s Britain. Actioning is widely used in British theatre and taught at many British drama schools in conjunction with a Stanislavskian training, but in its most common form it can probably be traced back to the Joint Stock Theatre Company in the 1970s.

Max Stafford-Clark, co-founder of Joint Stock and now artistic director of Out of Joint, is the name most usually associated with Psycho-physical Actioning, and in fact he still uses actioning routinely as one of the starting points for investigating a play. Nigel Terry, who worked with Stafford-Clark on the Joint Stock 1983 production of Howard Barker's Victory, writes:

You break the whole thing into sections, and you use transitive verbs on every single act and action. Max might have done that himself, or partly done it before rehearsal. Then he'd go through it with the actors. So you've got a structure, like a framework, that you can always refer back to.'

Surprisingly, however, he acknowledges that the technique's originator was in fact not himself but his co-director, Bill Gaskill, "I learned about actioning from Bill", Stafford-Clark writesii. During rehearsal for the 1975 Joint Stock production of David Hare's Fanshen, Gaskill apparently became frustrated by some of the actors on this production declaring that 'my character wouldn't do that' when asked to follow directions within the text. The actioning technique was born out of the need to move away from what Gaskill saw as a 'Methodbased' Freudian approach to text, which focused on individual motivation (the 'why'), to a more 'intentional' analysis, which was more concerned with exploring the nature of a verbal or physical action, its intention and its effect (the 'what'). 
Gaskill felt that many actors, particularly those trained in the American 'Method', placed too much trust in the inner emotional state of the character to spark the motivation to speak and to produce clarity of action and intention on the text. For him, the action itself was the most important thing - what the character does - to whom, in what manner, and with what intention. If an actor could find that journey, both the character and the inner journey would then become apparent both to the actor and to the audience.

Stafford-Clark developed Gaskill's idea into the 'actioning' process, in which the actor does not set a series of physical actions, but starts by translating his own lines of text (and his stage directions) into a series of simple transitive action verbs which express his character's immediate intention in relation to one or more other characters, and suggest to the actor how he might speak each line of text. In this way each vocal choice which the actor makes springs from his understanding of the character's objective, and how it manifests itself in a specific strategic moment. In effect, the action verbs are the actor's personal analysis of what the author and the play are demanding from him.

The starting point of this technique is the division of the dramatic text, individually by the actor or collectively by the acting company, into separate phrases or 'thoughts', as in this example from Act 1 of Arthur Miller's The Crucible:

MARY WARREN: What'll we do?/ The village is out!/ I just come from the farm; the whole country's talkin' witchcraft. /They'll be callin' us witches, Abby!

MERCY: [pointing and looking at Mary Warren]:/ She means to tell, I know it.ii

This short exchange, from the first act, is between Mary Warren and Mercy Lewis, two of the girls who have been caught dancing in the woods. Also present in the scene are Abigail Williams (the ringleader) and Betty Parris (the youngest girl, lying apparently unconscious.) The forward slashes represent 
the thought-changes. A new thought is defined as a change of subject, whether slight or considerable, which implies a shift in energy, intensity or address. In this case the frequency of thought-changes in Mary Warren's speech indicates that not only is she agitated, and therefore thinking quickly, but that she is trying many strategies to make her listeners understand and respond. This also implies that the listeners (Abigail and Mercy) are not responding positively.

Each thought is then assigned a transitive verb, expressed either in the infinitive - 'to probe', 'to flatter', 'to squeeze', or in the first person singular - 'I probe', 'I flatter', I squeeze', or in third person singular - 'probes', 'flatters', 'squeezes'. The verb selected depends entirely on the nature of the textual 'thought' for that particular character within the given circumstances of the play and on the underlying intention of that thought. The verbs all need to be transitive, because the fundamental principle of actioning is that all dramatic dialogue is 'intentional', and that each spoken phrase seeks to affect the hearer in a particular way, even when that intention is not immediately apparent. It is also essential that all verb choices are made within the context of the character's main objective for the play and their smaller 'want' within each scene, so that the action verb never works against the objective.

The action verbs encapsulate Mary Warren's intentions, moment by moment, in terms of how she wants her listeners to be affected. The examples below are just possible choices, a starting point for the actor. They are not fixed, and may need to be re-thought during the rehearsal process. It is worth noting here that action verbs do not and should not describe the actual effect which a line of text will have on another character - they describe only the intended effect. Most actions in dramatic scenes in fact fail to achieve the intended effect, which is why they are then followed up with other or stronger actions.

MARY WARREN:

\begin{tabular}{|l|l|}
\hline TEXTUAL 'THOUGHT' & ACTION VERB
\end{tabular} 


\begin{tabular}{|l|l|}
\hline What'll we do? & I appeal to \\
\hline The village is out! & I alarm \\
\hline $\begin{array}{l}\text { I just come from the } \\
\text { farm; the whole } \\
\text { country's talkin' } \\
\text { witchcraft. }\end{array}$ & I frighten \\
\hline $\begin{array}{l}\text { They'll be callin' us } \\
\text { witches, Abby! }\end{array}$ & \\
\hline
\end{tabular}

\section{MERCY LEWIS:}

\begin{tabular}{|l|l|}
\hline [pointing and looking at & I alert \\
Mary Warren]:She & \\
means to tell, I know it. & \\
\hline
\end{tabular}

Where there are more than two characters on stage, it is also necessary, prior to selecting a verb, to decide who is being addressed, because the target of the action will often dictate the choice of verb. In this case, for example, Mercy might play different action verbs to Mary (low status) from those she plays to Abigail (high status). For this reason I have also included the direction of the action in the table below:

MARY WARREN:

\begin{tabular}{|l|l|l|}
\hline TEXTUAL 'THOUGHT' & ACTION VERB & DIRECTED TO \\
\hline What'll we do? & I appeal to & Abigail and Mercy \\
\hline The village is out! & I alarm & Abigail and Mercy \\
\hline $\begin{array}{l}\text { I just come from the } \\
\text { farme whole }\end{array}$ & I frighten & Abigail and Mercy \\
\hline
\end{tabular}




\begin{tabular}{|l|l|l|}
\hline $\begin{array}{l}\text { country's talkin' } \\
\text { witchcraft. }\end{array}$ & \\
\hline $\begin{array}{l}\text { They'll be callin' us } \\
\text { witches, Abby! }\end{array}$ & I warn & Abigail \\
\hline
\end{tabular}

\section{MERCY LEWIS:}

\begin{tabular}{|l|l|l|}
\hline [pointing and looking at & I alert & Abigail \\
Mary Warren]:She & & \\
means to tell, I know it. & & \\
& & \\
\hline
\end{tabular}

The discussion through which a company of actors arrives at these choices is generally very productive, involving as it does a detailed examination of the character's objective in relation to a moment of verbal action. This has the effect of focusing the company on specifics, and avoiding lengthy character analyses and 'psycho-babble'.

Having selected the verbs, tried them out on the spoken text, and moved into the rehearsal process, the actor is faced with the challenge of physicalising action verbs in a way which incorporates gesture, psychological intention and specificity of thought on the text. This is arguably a crucial stage in the actioning process, yet many actors and directors seem vague about it. Even Stafford-Clark does not ask his actors directly to physicalise the action verb, relying instead on the actor's own ability to somehow incorporate the action choices into the rehearsal process. iv

The question then arises of how the actor reconciles the action verb (the preidentified demand of the text) with his own experiences and impulses within the lived and inhabited world of the play. Can the action verbs, manifested in particular readings of each thought within the text, be simply selected, aired, and then put aside, effectively submerged into the subconscious and remaining as underlying conditioners of otherwise spontaneous vocal and 
physical choices? The rest of this article deals with my exploration of this question and on how the technique of psycho-physical actioning can make the transition from the psycho to the physical.

I first worked with Psycho-physical Actioning in 1989, when, as an actor working on a production of The Provoked Wife, I was asked by the director, along with the rest of the company, to engage in the process of identifying transitive verbs as a starting point for rehearsing the scenes. None of the actors in our company had any previous experience of this rehearsal technique, and its introduction, without much prior discussion, met with confusion (and ultimately indifference) especially as the process involved a great deal of 'table work' within an already limited rehearsal period.

The confusion grew when we started to work the scenes and there seemed to be no connection between the 'actioning' we had done round the table, and the means by which we then worked towards the physical realisation of the play. It was as though our chosen action verbs were supposed in some way to reveal themselves in our physical and vocal choices without any conscious effort on our part. The reality was that we all largely ignored the action verbs and worked the scenes in our own time, using our own processes.

My next encounter with Psycho-physical Actioning was in the late 1990s, when as a teacher in a major drama school I worked with another teacher who had trained as an actor at Rose Bruford Academy (a major UK drama school and Stanislavski research centre) and for whom actioning lay at the heart of the rehearsal process. Together we began to build actioning into the core training. After a bit of practice, the students proved very able in selecting action verbs for their text, but the next stage in the process presented them with more difficulty. It became clear to us that the action verb, once identified, could not inform the realisation of a thought in the acting space unless the body could somehow take on the verb and build it into a lived psycho-physical gesture. A series of actions would then become a series of gestures which could serve as the actor's 'pathway' through the scene. As the gesture changed, so would the thought and the energy of the thought, and thus, in 
theory at least, the actor could find his way through the scene with physical, vocal and emotional clarity.

Like many practitioners of Psycho-physical actioning, we began with 'table work', working as director and company through the text to establish the character objectives, mark out the textual thoughts and assign a verb to each thought. Having made their choices, the actors then learned the lines and the action verbs together, so that a firm association was formed.

The first challenge was actually to find the right verbs. Sometimes it seemed that a character, particularly where he had a long speech with many thoughts but the same underlying intention, just seemed to be performing the same verb over again. After a while, however, it became clear that each thought had its own quality, which could be captured precisely using similar but different verbs, as in the following passage from Act 2 of The Crucible in which Elizabeth Proctor tries to convince her husband to go to town and put a stop to the witch hunt:

ELIZABETH: The Deputy Governor promise hangin' if they'll not confess, John./ The town's gone wild, I think./ She speak of Abigail and I thought she were a saint, to hear her./ Abigail brings the other girls into the court, and where she walks the crowd will part like the sea for Israel./ And folks are brought before them, and if they scream and howl and fall to the floor - the person's clapped in the jail for bewitchin' them. ${ }^{\vee}$

Since this is a narrative speech with a single theme, whose purpose is to shock Proctor into action, one might feel justified in assigning the single action verb 'I galvanise' to the entire passage. Yet this would fail to address the different strategies which Elizabeth employs during the speech, and to capture the unique quality of each thought. Below is a tabular analysis of the speech, which, by assigning different (though often similar) verbs to each thought, empowers the actor to discover those distinct shades of meaning. 
Once again, these verbs should be seen as the choices of this actor in this company, not as absolutes.

\begin{tabular}{|l|l|}
\hline TEXTUAL THOUGHT & ACTION VERB \\
\hline $\begin{array}{l}\text { The Deputy Governor promise } \\
\text { hangin' if they'll not confess, John. }\end{array}$ & I correct (his previous statement) \\
\hline The town's gone wild, I think. & I alarm \\
\hline $\begin{array}{l}\text { She speak of Abigail and I thought } \\
\text { she were a saint, to hear her. }\end{array}$ & I astonish \\
\hline $\begin{array}{l}\text { Abigail brings the other girls into the } \\
\text { court, and where she walks the crowd } \\
\text { will part like the sea for Israel. }\end{array}$ & I bemuse \\
\hline $\begin{array}{l}\text { And folks are brought before them, } \\
\text { and if they scream and howl and fall } \\
\text { to the floor - the person's clapped in } \\
\text { the jail for bewitchin' them. }\end{array}$ & I shock \\
\hline
\end{tabular}

The allocation of a separate verb to each thought, despite the broad intention being the same throughout, highlights the fact that in pursuit of an objective we can use many strategies. We don't have to be trained in rhetoric to know that to present a convincing case, it is necessary to use variation of volume, pace, tone and musicality with each new thought, so that whatever the actual words, the listener has the impression of not one convincing point but a great many. The action verbs offer suggestions to the actor, which guide the changes of thought and energy.

The next challenge we faced was to find that crucial link between the action verb and the physical gesture. Some action verbs such as 'I shake', 'I poke' or 'I grab' are already highly physical, but very often the given circumstances of the text do not permit them to be carried out literally. Others, such as 'I criticise' or 'I belittle' don't seem to stimulate the actor into any gestural expression, and often the pressure to find the gesture leads to vague 
generalised 'arm-flapping' in which there is very little definition and still less embodied intention. This may be partly because the trainee actors' own gestural vocabulary, being that of the early twenty-first century, tends away from this kind of clear physical embodiment of intention, and partly because the verbs alone are insufficient to stimulate the physical imagination, at least not in an immediate, spontaneous way.

We also ran into the problem that with the body disconnected from the intention, actors would tend to push into 'forward space' seeming to want to 'get into the face' of other actors. With every action 'going forward', actors would quickly run out of choices, the voice and body would fall into patterns, and the actor would end up playing every action in the same way.

Gradually it dawned upon us that for action verbs to work, the actor had to be trained, not just to allow the expression of the gesture in the body, but to develop his or her whole psycho-physical 'vocabulary', so that expressive gesture could become an embedded part of the actor's physical life.

Working from text, we began to explore the dynamics of gesture and proxemics (spatial relationships) and to examine both its personal and its social aspects. What we discovered was that the actors quickly came up with ideas about how the action verb translated into gesture, and that with a little practice, could take those gestures into the body and into their spatial choices in a way which rang true to them and generated thoughts and intentions which in turn played back through the text.

Revisiting the example above: we discovered that most action verbs - even when largely psychological in nature - can within their particular context suggest physical choices, which may vary from actor to actor, but which offer any actor a clear physical journey closely linked to character intention:

Textual thought

Action verb

Physical possibilities 


\begin{tabular}{|l|l|l|}
\hline & & $\begin{array}{l}\text { discovered by the actor } \\
\text { in the space }\end{array}$ \\
\hline $\begin{array}{l}\text { The Deputy Governor } \\
\text { promise hangin' if they'll } \\
\text { not confess, John. }\end{array}$ & $\begin{array}{l}\text { I correct (his previous } \\
\text { statement) }\end{array}$ & $\begin{array}{l}\text { Forward, getting into } \\
\text { his eyeline to make } \\
\text { sure he can't avoid the } \\
\text { issue }\end{array}$ \\
\hline $\begin{array}{l}\text { The town's gone wild, I } \\
\text { think. }\end{array}$ & I alarm & $\begin{array}{l}\text { Moving away, directing } \\
\text { his attention to the } \\
\text { outside world and its } \\
\text { dangers }\end{array}$ \\
\hline $\begin{array}{l}\text { She speak of Abigail and } \\
\text { I thought she were a } \\
\text { saint, to hear her. }\end{array}$ & I astonish & $\begin{array}{l}\text { An upward gesture of } \\
\text { mock-worship }\end{array}$ \\
\hline $\begin{array}{l}\text { Abigail brings the other } \\
\text { girls into the court, and } \\
\text { where she walks the } \\
\text { crowd will part like the } \\
\text { sea for Israel. }\end{array}$ & I bemuse & $\begin{array}{l}\text { A backward move and } \\
\text { self-protective gesture } \\
\text { of mock-awe }\end{array}$ \\
\hline $\begin{array}{l}\text { And folks are brought } \\
\text { before them, and if they } \\
\text { scream and howl and fall } \\
\text { to the floor - the person's } \\
\text { clapped in the jail for } \\
\text { bewitchin' them. }\end{array}$ & I shock & $\begin{array}{l}\text { A partial acting-out of } \\
\text { the girls' hysteria. }\end{array}$ \\
\hline
\end{tabular}

The actors arrived at these ideas, firstly by asking a series of questions for which the action verb is merely the starting point, and secondly by exploring those ideas in the space. This process is something we came to call 'unpacking the action' - investigating the questions of who is to be affected, to what end, and with what strategy. We did this because we realised that within the complexity of most dramatic dialogue, the body is much more than a mere amplifier of the spoken word, although, it can be that too. 
For the first action in the table above, the actor playing Elizabeth felt the need to use her body to 'correct' Proctor. Her hands, while not actually touching him, seemed to want to reshape and adjust him. For the second action, 'I alarm', the actor experimented with a sudden explosive gesture, lifting her head and flinging her arms outwards, this being a gesture she associated with 'alarming' someone - the physical equivalent of shouting 'Boo!'. Yet from the first, this gesture struck both her and the rest of the company, as inorganic and false. I asked her to play the line without trying to force the body into a particular gesture, and without thinking she gestured towards the door and moved her body in that direction, as if to force him to look (towards the town). When asked why, she considered for a moment and then said that it seemed the best way of making Proctor wake up to the seriousness of the situation.

We began to realise that the body and the voice, rather than duplicating each other's gestures, often work in a complementary way, fulfilling different functions within the intentional moment. The voice may deliver the tone and quality of the action verb, while the body directs the attention of the listener towards locations and events described, which could be within or outside the room. In other words, when Elizabeth 'alarms' Proctor, it is not her body she wants him to find alarming, but what her body is pointing to - in this case the chaos in Salem.

In this case it was clear that the actor's understanding of the action verb within a context - I alarm him with a particular image/idea (which the text offers) in order to make him do what I want - gave her enough information to make the body responsive and functional within the transaction. Significantly, this simple distillation of the intentional moment appeared to have enabled her to avoid playing an emotional state and instead play the argument from a specific inner need.

To return to the earlier example from Act 1: here the actor playing Mary Warren can also use her body in a number of ways, depending on the precise nature of the thought 
MARY WARREN:

\begin{tabular}{|c|c|c|}
\hline $\begin{array}{l}\text { LINE OF TEXT/STAGE } \\
\text { DIRECTION }\end{array}$ & ACTION VERB & POINTS TO \\
\hline What'll we do? & I appeal to & $\begin{array}{l}\text { The shared problem and } \\
\text { the need to act together }\end{array}$ \\
\hline The village is out! & I alarm & The events in the village \\
\hline $\begin{array}{l}\text { I just come from the } \\
\text { farm; the whole } \\
\text { country's talkin' } \\
\text { witchcraft. }\end{array}$ & I frighten & $\begin{array}{l}\text { The events not just in } \\
\text { the village but in the } \\
\text { whole country }\end{array}$ \\
\hline $\begin{array}{l}\text { They'll be callin' us } \\
\text { witches, Abby! }\end{array}$ & I warn & $\begin{array}{l}\text { The girls and their } \\
\text { shared danger }\end{array}$ \\
\hline
\end{tabular}

MERCY LEWIS:

\begin{tabular}{|l|l|l|}
\hline $\begin{array}{l}\text { [pointing and looking at } \\
\text { Mary Warren]: }\end{array}$ & I expose & $\begin{array}{l}\text { Mary Warren's fear and } \\
\text { anxiety }\end{array}$ \\
\hline $\begin{array}{l}\text { She means to tell, I } \\
\text { know it. }\end{array}$ & I alert & $\begin{array}{l}\text { A point in the near } \\
\text { future when Mary will } \\
\text { expose them all }\end{array}$ \\
\hline
\end{tabular}

The process of selecting and 'unpacking' these verbs forces the actor to ask key questions about the situation, and to make choices about intention, physical interaction, meaning and address. Mary's first thought/action is relatively clear. It is probably addressed to both girls, but principally to Abigail as the acknowledged leader and the brains of the group. Mary appeals to Abigail for leadership. We cannot decide in advance how Abigail reacts to Mary's appeal, but we know she doesn't immediately say or do anything. We can assume, therefore, that Mary's second action - I ALARM - is a reaction to Abigail's inaction, and her third action - I FRIGHTEN - is an amplification of 
this. Her last action, I WARN, implies that there is a real and imminent danger of the outside world invading the room and accusing them all.

The action verb, understood within the context of the scene and the play, helps the actor quickly to make a vocal choice, in terms of pitch, volume, pace, tone, articulation, stressing and musicality, which will as far as possible carry out the intention implied in the verb. As we have seen, every action, in addition to its primary intention, also contains another element which is strictly spatial and locational - the aspect of 'pointing'. In the table above, Mary Warren does not just use her emotional state (fear) to power her actions; she also points the listeners towards the events which have created that emotional state. It is of course much easier for the body to signal locations than it is for the voice, which means that the actor generally uses the body to do that pointing.

All this may sound very obvious, but it is astonishing how often the actor forgets the value of the body as a simple signifier and underliner of the spoken text. In real life we don't have to think about it, but if we watch people in dialogue we see very clearly how they unconsciously direct the listener's attention to both real and abstract locations/events with gestures of varying size, from an almost imperceptible shift of the head to a whole-body gesture or re-enactment. This is because our imaginations often work in a 'locational' way. By placing the subject of our spoken thoughts in a location relative to our bodies (even if that location is actually inside our bodies), we strengthen our own mental images, and by extension, we strengthen the mental images to which our listeners will then have access.

The physical dimension of the action verb can be identified as the directing of the listener, by the speaker, towards the location of whatever it is they need to see or understand. Interestingly, this may take the body in the opposite direction from the action itself. When Mary Warren 'alarms' Abigail and Mercy by telling them about the general consternation in the village, the energy of her action is directed towards them, but her body is pointing them towards something which is happening in the streets down below. Conversely, when 
Mary 'appeals' to Abigail for leadership, her body is somehow indicating the shared problem which they all have to face (including the sleeping Betty).

This duality in the function of the body can help the actor avoid getting stuck in forward space. In other words, if the total directional energy of the body is committed to the action verbs alone, then there will be a tendency to fixate on the other actor, which may 'trap' the body in a single forward gesture, within which the only possible variation will be in the voice, and in arm gestures. However, If the body is used as a 'signpost', which supports the action verb by locating the ideas of the text in specific places, then the body can find freedom, while still remaining in relationship to the other actor and committed to an intention.

In the example below, from the opening of Act 2 of The Crucible, both characters spend all or part of the exchange engaged in everyday physical tasks. Proctor is washing his face and hands (presumably a vigorous task given the job he has been doing and the fact the water is probably cold). Elizabeth is for most of this passage preparing and serving Proctor's meal. This means that for both actors playing these roles, the body's gestural contribution to the action verbs will manifest through and around these underlying activities.

The gestural choices in the last column below emerged from real practical explorations in the rehearsal space, in which the actors worked from impulse, but with an awareness of the first three columns.

\begin{tabular}{|l|l|l|l|}
\hline $\begin{array}{l}\text { LINE OF TEXT } \\
\text { ISTAGE } \\
\text { DIRECTION }\end{array}$ & ACTION VERB & POINTS TO & $\begin{array}{l}\text { PHYSICAL } \\
\text { GESTURE }\end{array}$ \\
\hline $\begin{array}{l}\text { ELIZABETH: } \\
\text { What keeps you } \\
\text { so late? }\end{array}$ & I chide & $\begin{array}{l}\text { Proctor's earlier } \\
\text { absence }\end{array}$ & $\begin{array}{l}\text { Slight gesture } \\
\text { towards the door }\end{array}$ \\
\hline It's almost dark. & I remind & Darkness outside & Looks towards the \\
\hline
\end{tabular}




\begin{tabular}{|c|c|c|c|}
\hline & & & window \\
\hline $\begin{array}{l}\text { PROCTOR: I } \\
\text { were planting } \\
\text { far out to the } \\
\text { forest edge }\end{array}$ & I appease & $\begin{array}{l}\text { The long distance to } \\
\text { the edge of the farm }\end{array}$ & $\begin{array}{l}\text { Pauses in his } \\
\text { washing, looks } \\
\text { towards her and } \\
\text { inclines his head } \\
\text { towards the place he } \\
\text { is talking about }\end{array}$ \\
\hline $\begin{array}{l}\text { ELIZABETH: } \\
\text { Oh, you're done } \\
\text { then. }\end{array}$ & I applaud & The size of the farm & $\begin{array}{l}\text { Steps back slightly, } \\
\text { as if to take in the } \\
\text { size of the area that } \\
\text { has been planted }\end{array}$ \\
\hline $\begin{array}{l}\text { PROCTOR: } \\
\text { Aye, the farm is } \\
\text { seeded. }\end{array}$ & I impress & $\begin{array}{l}\text { His own strength and } \\
\text { prowess. }\end{array}$ & $\begin{array}{l}\text { Finishes washing his } \\
\text { hands, flicks off } \\
\text { water, draws } \\
\text { attention to his hands }\end{array}$ \\
\hline $\begin{array}{l}\text { PROCTOR: } \\
\text { The boys } \\
\text { asleep? }\end{array}$ & $\begin{array}{l}\text { I acknowledge } \\
\text { (her contribution) }\end{array}$ & $\begin{array}{l}\text { The quiet in the } \\
\text { house }\end{array}$ & $\begin{array}{l}\text { Gestures towards the } \\
\text { stairs }\end{array}$ \\
\hline $\begin{array}{l}\text { ELIZABETH: } \\
\text { They will be } \\
\text { soon. }\end{array}$ & $\begin{array}{l}\text { I accept (his } \\
\text { acknowledgment) }\end{array}$ & $\begin{array}{l}\text { The quiet in the } \\
\text { house }\end{array}$ & $\begin{array}{l}\text { Looks towards the } \\
\text { stairs }\end{array}$ \\
\hline $\begin{array}{l}\text { ELIZABETH: } \\
\text { She Goes to } \\
\text { the fireplace, } \\
\text { proceeds to } \\
\text { ladle up stew in } \\
\text { a dish. }\end{array}$ & $\begin{array}{l}\text { I feed (non- } \\
\text { verbal) }\end{array}$ & $\begin{array}{l}\text { Her good } \\
\text { housekeeping }\end{array}$ & $\begin{array}{l}\text { Ladles up the stew } \\
\text { with care and } \\
\text { dexterity }\end{array}$ \\
\hline $\begin{array}{l}\text { PROCTOR: } \\
\text { Pray now for a } \\
\text { fair summer. }\end{array}$ & I cheer & $\begin{array}{l}\text { The possibility of a } \\
\text { good harvest and } \\
\text { prosperity for the } \\
\text { family }\end{array}$ & $\begin{array}{l}\text { Gestures outwards } \\
\text { and upwards as if } \\
\text { passing responsibility } \\
\text { to God and the } \\
\text { elements }\end{array}$ \\
\hline ELIZABETH: & I freeze & Her present & Pauses in the ladling \\
\hline
\end{tabular}




\begin{tabular}{|c|c|c|c|}
\hline Aye. & & unhappiness & $\begin{array}{l}\text { and turns her head } \\
\text { slightly away from } \\
\text { him }\end{array}$ \\
\hline $\begin{array}{l}\text { PROCTOR: Are } \\
\text { you well today? }\end{array}$ & I probe & Her coldness & $\begin{array}{l}\text { Takes a step towards } \\
\text { her }\end{array}$ \\
\hline $\begin{array}{l}\text { ELIZABETH: I } \\
\text { am. }\end{array}$ & I stall & $\begin{array}{l}\text { Her lack of readiness } \\
\text { to talk }\end{array}$ & $\begin{array}{l}\text { Faces him and } \\
\text { attempts a smile }\end{array}$ \\
\hline $\begin{array}{l}\text { ELIXABETH: } \\
\text { She brings the } \\
\text { plate to the } \\
\text { table, and, } \\
\text { indicating the } \\
\text { food: It is a } \\
\text { rabbit. }\end{array}$ & I divert & $\begin{array}{l}\text { The quality of the } \\
\text { food }\end{array}$ & $\begin{array}{l}\text { Places the dish on } \\
\text { the table with a level } \\
\text { of ceremony, then } \\
\text { stands back }\end{array}$ \\
\hline
\end{tabular}

Here we see that where the character is engaged in an unrelated underlying activity, the actor finds ways either to pause the activity, or to change the manner in which they undertake it, in order for the 'pointing' to take place. Hence the audience reads the thought in the body through the divergence from the performance of the 'everyday' task. For the actor too, the experience of feeling a routine task transformed or interrupted by the verbal and physical expression of an intention, has a ring of truth about it which pulls him into the world of the play and helps him really 'live' the scene.

In taking the 'psycho' (intention) into the 'physical' (gesture), we cannot force actors to perform predetermined gestures - we can only give them enough information, about intention, space, locations and relationship, for the body to be able to 'locate itself' within the world of the play and the dialogue. During the early part of rehearsal there is a constant 'interchange' between the actor's intellectual investigation of the text and his instinctual explorations in the space - in other words, a dialogue between ideas and impulses. In this way the body teaches the mind and the mind teaches the body. 
Having found a possible physical form for each action verb, it is often useful for actors to try them out while speaking the action verbs instead of the dialogue itself, playing a whole scene with 'I accuse, I rebuke, I push away etc' spoken aloud as an 'alternative' text. To do this three or four times helps to 'peg' the gesture to an intention. It also exposes any gesture (or indeed any action verb) which isn't working and needs to be changed. By speaking the actions and playing the moves and gestures through, the actor constructs and lives the physical and intentional journey of the scene before he starts to speak the text, which means that the text can then emerge from the actor's psycho-physical understanding of that journey.

Significantly, this 'speaking the action' exercise also helps the actor to experience each psycho-physical action as a reaction to the other actor. . Even in the early stage of actioning, all actions should be played in the context of the immediate relationship, so that whatever their gestural nature, the actor is always in reaction to what he experiences. It is essential that actors engaged in the actioning process move very quickly into 'reactive' mode, otherwise the action gestures will become choreography rather than the physical 'vocabulary' through which to channel an impulse.

So what happens to the action verbs as rehearsal proceeds? Clearly no actor can go into the middle or final stages of rehearsal 'painting by numbers'. At some stage the actions have to become embedded in the actor's psyche and body, so that he is able to be truly present as the character in relationship to other characters. In fact this usually happens organically as part of the process. Very quickly the actor can stop thinking about the actions and free himself up to respond to the moment-by-moment events within a scene. However, the basic action choices, both verbal and physical, are always there in the background. In later rehearsal and performance they may evolve, or even change completely as the actor makes new discoveries, but if any of the actor's intentions become blurred or ill-defined, or if thought-changes don't quite register, the 'map' is still there to be referred to. 
My first response to the technique of Psycho-physical Actioning when I encountered it more than twenty years go, was that it was prescriptive and disconnected from the actor's instincts. I now believe it to be a useful way of conducting a dialogue between text and impulse, which, provided the actor approaches it in a spirit of exploration, can help him find a connection to the character and to live more fully in the physical world of the play.

\footnotetext{
' Roberts, P and Stafford-Clark, M (2007) Taking Stock, London, Nick Hern Books

ii ibid

iii Miller, A (1968) The Crucible, London: Penguin Books

iv Taken from a live interview with Max Stafford-Clark - July 2012

${ }^{\vee}$ Miller, A, op. cit.
} 